\title{
EMPIRE RHEUMATISM COUNCIL SIXTEENTH ANNUAL REPORT
}

The sixteenth annual report of the Empire Rheumatism Council was presented by the Chairman, Lord Horder, at the Annual General Meeting held on April 29, 1953, at 11 Chandos Street, London, W.1. The Chairman first recorded with regret the deaths of Lord Broadbridge, VicePresident of the Council, and Mr. H. L. Jackson, Life-Councillor.

The incorporation of the Council had brought about an enlarged membership, and he hoped that their new friends would be active in spreading interest in their work.

Research.-The work of the Council in this field had been greatly increased in the past year. Dr. A. A. Henly assisted by Miss M. I. Potter had continued his work at the Hospital of St. John and St. Elizabeth on ACTH and cortisone, particularly on their relation to urinary steroid excretion. "Butazolidin" was found to have little or no effect in this direction, though clinically useful in other respects. Their thanks were due to Messrs Roche Products Ltd. for financing this work.

The work of Dr. J. D. Billimoria at the Westminster Hospital Medical School had been greatly assisted by the fact that the School had provided a high pressure autoclave for carrying out dehydrogenation reactions.

The holders of the "Elizabeth Macadam Fellowship" had sent in excellent reports of progress. Dr. J. L. Potter had completed his studies on ankylosing spondylitis chiefly in relation to radiotherapy at the Northern General Hospital, Edinburgh, under Dr. J. J. R. Duthie; Dr. B. F. Matthews had been investigating physical and biochemical changes in ageing human cartilage at the Canadian Red Cross War Memorial Hospital, Taplow, under Dr. E. G. L. Bywaters.

Dr. J. M. Tweed, the first "Philip Gray Fellow", had been working on the causation of rheumatoid arthritis at the West London Hospital under Dr. W. S. C. Copeman.

An application had been received from Dr. E. Wittkower of McGill University, Montreal, who was undertaking a study of "Rheumatoid Arthritis in Two Contrasting Communities", and the Treasury had been asked for permission to transfer sterling currency to Canada.

An offer from the Merck Co. of the U.S.A. to supply sufficient cortisone acetate to maintain fifty patients on oral therapy for 12 months (and also to maintain in perpetuo those patients who remained on therapy after that time) had been gladly accepted by the Executive Committee. It was proposed to carry out trials of cortisone and aspirin at nine British centres in 1953.

It had been decided by the Scientific Co-ordinating Committee that two Empire Rheumatism Council fellowships should be awarded in 1953 for the study of:

(i) the adrenal hormones (ii) the proteins in connective tissue.

Special biopsy needles had been designed and made for use at the West London Hospital through the generosity of Mr. D. D. Mynott.

Education.-All the Regional Hospital Board areas were now represented on the Regional Sub-Committee and this committee had begun by obtaining information on the state of facilities for rheumatism treatment and research in each area. The Post-Graduate Lecture Demonstrations had been continued at the Arthur Stanley Institute, Middlesex Hospital, and instructive clinical meetings held by the Heberden Society had been well attended.

Members had been invited to the International Congress of Physical Medicine in 1952, and a good many members proposed to attend the Congress of the European League against Rheumatism at Geneva and Aix-lesBains in August, 1953.

Commonwealth.- The branches in Canada, Australia, New Zealand, affiliated to the Council continued to report satisfactory progress and it was hoped that as soon as a representative appointment for Canada was made, a further Commonwealth Sub-Committee Meeting would be arranged. Copies of the minutes of meetings received from the Dominions disclosed that all three autonomous affiliated branches were forging ahead. Dr. A. J. Cronin, President of the New Zealand affiliated branch, had had the opportunity of joining their deliberations by attending various meetings and conferences whilst in England.

Finally, the Chairman commended the loyal and devoted services of the members of the key administrative committees, whom it was proposed to re-elect for a further term of office, and he congratulated the Finance Committee upon the skilful management which had enabled it to show a surplus at the end of the year.

\section{NEW OFFICERS}

At the Annual General Meeting, Lord Horder, who has been Chairman of the Council since 1936, announced his resignation. Dr. W. S. C. Copeman was elected in his place, on the proposition of Lord Webb-Johnson, who was re-elected Vice-Chairman. Dr. Oswald Savage was elected Honorary Medical Secretary, and Dr. R. M. Mason deputy Medical Secretary.

\section{CORONATION LECTURE}

Professor Sir Henry Cohen will deliver a lecture on "The Concept of Collagen Disease" at the Royal Society of Medicine (Barnes Hall), 1 Wimpole Street, London, W.1, on Thursday, July 2, 1953, at 8.15 p.m. 